\title{
PELATIHAN MANAJEMEN PERSEDIAAN DAN TATA LETAK USAHA KECIL PENGOLAHAN BATAKO KAMPUNG CISEUPAN KOTA CIMAHI
}

\author{
Resi Juariah Susanto \\ resi.juariah@gmail.com \\ Anton Mulyono Azis \\ SEKOLAH TINGGI ILMU EKONOMI EKUITAS
}

\begin{abstract}
ABSTRAK
Progam pengabdian masyarakat yang dilakukan bertujuan untuk memberikan pelatihan sebagai salah satu upaya meningkatkan keterampilan untuk pelaku usaha di lingkungan Pengolahan Batako Kampung Ciseupan Kota Cimahi berupa pelatihan manajemen persediaan dan tata letak. Masalah yang sering dihadapi oleh para pelaku usaha diantaranya adalah kurang dalam mengatur tata letak dan mengatur persediaan pada proses produksi. Hal ini disebabkan minimnya pengetahuan pelaku usaha mengenai cara bagaimana pengaturan tata letak dan persediaan yang baik dalam suatu proses produksi sebagai sarana pembantu dalam melakukan usaha oleh para pelaku usaha di lingkungan Kampung Ciseupan Kota Cimahi. Fenomena yang terjadi saat ini adalah bahwa pelaku usaha masih sangat sederhana dan ala kadarnya dalam melakukan pengaturan tata letak dan persediaan yang ada dimana dapat memakan waktu dan biaya karena kurangnya pengaturan tersebut. Objek Program Pengabdian Masyarakat ini adalah pelaku Pengolahan Batako Kampung Ciseupan Kota Cimahi. Solusi yang diberikan berupa Pelatihan Manajemen Persediaan dan Tata Letak Pengolahan Batako Kampung Ciseupan Kota Cimahi. Kesimpulan dari pengabdian ini adalah bahwa masih sangat dibutuhkan pembelajaran bagi masyarakat sekitar dalam mengelola usahanya dari segi pengaturan tata letak dan pengaturan persediaan dimana tata letak dapat memaksimalkan tempat yang ada sedangkan untuk persediaan para pengusaha dapat memaksimalkan biaya.
\end{abstract}

Kata Kunci: Manajemen Persediaan, Manajemen Tata Letak, Pengolahan Batako.

\section{PENDAHULUAN}

Kampung Ciseupan merupakan salah satu dari lima belas desa yang termasuk ke dalam Kelurahan Cibeber Kecamatan Cimahi Selatan, Kota Cimahi. Kampung ini termasuk wilayah bebas banjir, karena secara geografis termasuk dataran tinggi. Kampung Ciseupan berbatasan dengan :

a) Sebelah Utara berbatasan dengan Desa Pancanaka. b) Sebelah Selatan berbatasan dengan Desa Padakasih.

c) Sebelah Timur berbatasan dengan Desa Leuwigajah.

d) Sebelah Barat berbatasan dengan Desa Cibeber Hilir.

Saat ini, di Kampung Ciseupan terdapat sekitar 60 pengrajin batako tersebar di beberapa Rukun Warga (RW) yang berpusat di RW 08. Usaha batako sudah dimulai sejak tahun 1960an, dan dilakukan secara turun temurun sampai saat ini. Batako sebagai salah satu bahan bangunan, merupakan produk substitusi bata merah 
yang bahan baku utamanya adalah pasir dan memiliki ketergantungan yang tinggi terhadap kondisi cuaca.

Produksi batako dalam satu hari ratarata berkisar antara 400-500 buah. Namun, produksi tidaklah dilakukan setiap hari, tergantung kepada kondisi cuaca. Jika cuaca panas, maka produksi dilakukan setiap hari, sebaliknya apabila sedang musim penghujan, proses produksi melambat bahkan tidak sama sekali. Hal ini dikarenakan, proses finishing batako yang haruslah dalam keadaan kering sempurna agar didapatkan batako yang berkualitas baik dan kuat.

Salah satu pengrajin batako yaitu Bapak Ade Taryana, merupakan generasi penerus kedua. Produk batako Bapak Ade Taryana belum memiliki merk, omzetnya mencapai Rp 1.000.000,00/bulan. Jika sedang ada order makloon dari pengrajin lain, omset dapat meningkat sebesar Rp 2.000.000,00 /bulan belum dikurangi biaya sewa alat, lahan dan bahan baku. Alat cetak yang digunakan masih menyewa dari pengrajin yang memiliki kelebihan alat cetak dengan sebesar Rp 40,00 dari setiap satu buah batako yang diproduksi dengan harga jual per buahnya Rp 450,00.

Tenaga kerja mayoritas adalah lakilaki yang berasal dari hubungan keluarga dan tinggal di lingkungan sekitar Ciseupan. Ini disebabkan karena proses pengerjaan batako yang memerlukan kekuatan lebih, pada saat mencetak harus dipress dengan tangan serta saat membuat adukan pasir dengan air.

Hasil survey yang dilakukan sebelumnya menunjukan bahwa masalah yang dihadapi oleh para pengolah batako kampung Ciseupan Kota Cimahi bahwa cukup khawatir dengan barang yang dihasilkan akan tetapi masih tersimpan sebagai barang persediaan dan belum diambil oleh pemesan dan masalah tata letak alur proses produksi yang belum tertata dengan baik.
Pelaku pengolah batako berpikir bahwa dalam penyimpanan persediaan barang yang dapat berakibat barang yang disimpan terlalu lama akan menjadi barang yang berkualitas buruk. Biasanya barang berkualitas buruk juga di sebabkan oleh faktor cuaca yang dapat mengubah kualitas batako tersebut.

Selain persediaan barang juga dapat dilihat dari tata letak antara tempat pembuatan dan letak persediaan yang tidak dekat dan cukup memakan waktu untuk pengerjaan dalam pengolahan batako. Lokasi pengerjaan ada yang memiliki ruang terbuka yang cukup luas dan ada juga yang memang memiliki lahan yang sangat sempit untuk mengolah batako tersebut. Dalam masalah ini termasuk kedalam tata letak berorientasi produk yang diorganisasikan di sekeliling produk atau kelompok produk yang sama yang bervolume tinggi dan bervariasi rendah (Heizer dan Render, 557: 2009) dimana memiliki kelemahan berupa volume produk yang tinggi, adanya pekerjaan yang harus terhenti pada setiap titik yang mengakibatkan seluruh kegiatan terganggu dan kurangnya fleksibilitas dalam menangani produk atau tingkat produksi yang berbeda.

Karena adanya fenomena tersebut, maka program pengabdian masyarakat yang akan dilakukan diharapkan mampu meningkatkan keefektifan dan pengoptimalan persediaan juga tata letak dalam pengolahan batako di kampung Ciseupan Kota Cimahi.

\section{METODE PELAKSANAAN}

Metode pelaksanaan dalam pengabdian ini adalah:

\section{Tabel 3.1 Metode Pelaksanaan Pengabdian}

\begin{tabular}{|l|l|l|}
\hline TAHAPAN & METODE & \multicolumn{1}{|c|}{ HASIL } \\
\hline $\begin{array}{l}\text { Metode } \\
\text { pendekatan } \\
\text { masalah }\end{array}$ & Metode & Pemaha- \\
pendekatan & man \\
yang & persamaan \\
\hline
\end{tabular}




\begin{tabular}{|c|c|c|}
\hline & $\begin{array}{l}\text { ditawarkan } \\
\text { untuk } \\
\text { menyelesai- } \\
\text { kan persoalan } \\
\text { mitra adalah } \\
\text { dengan } \\
\text { melakukan } \\
\text { diskusi antara } \\
\text { tim STIE } \\
\text { Ekuitas } \\
\text { dengan } \\
\text { dengan para } \\
\text { pengrajin } \\
\text { untuk lebih } \\
\text { mengetahui } \\
\text { kendala dan } \\
\text { hambatan } \\
\text { dalam } \\
\text { menjalankan } \\
\text { usaha }\end{array}$ & $\begin{array}{l}\text { persepsi } \\
\text { dari pihak } \\
\text { yang } \\
\text { terkait, } \\
\text { dalam hal } \\
\text { ini tim } \\
\text { STIE } \\
\text { Ekuitas } \\
\text { dengan } \\
\text { pengrajin } \\
\text { batako }\end{array}$ \\
\hline $\begin{array}{l}\text { Prosedur } \\
\text { kerja }\end{array}$ & $\begin{array}{l}\text { Pelatihan } \\
\text { manajemen } \\
\text { persediaan } \\
\text { dan tata letak } \\
\text { sebagai cara } \\
\text { untuk } \\
\text { mengatasi } \\
\text { persoalan } \\
\text { yang telah } \\
\text { dibahas } \\
\text { sebelumnya }\end{array}$ & $\begin{array}{l}\text { Modul } \\
\text { pelatihan } \\
\text { manaje- } \\
\text { men } \\
\text { persediaan } \\
\text { dan tata } \\
\text { letak }\end{array}$ \\
\hline $\begin{array}{l}\text { Rencana } \\
\text { Kegiatan }\end{array}$ & $\begin{array}{l}\text { Pelatihan } \\
\text { manajemen } \\
\text { persediaan } \\
\text { dan tata letak } \\
\text { dengan } \\
\text { mengguna- } \\
\text { kan modul } \\
\text { dan terjun } \\
\text { langsung ke } \\
\text { lapangan }\end{array}$ & $\begin{array}{l}\text { Modul } \\
\text { pelatihan } \\
\text { dan } \\
\text { mendam- } \\
\text { pingi para } \\
\text { pelaku } \\
\text { dalam } \\
\text { lapangan } \\
\text { ketika } \\
\text { dilakukan } \\
\text { simulasi } \\
\text { atau } \\
\text { pemberian } \\
\text { contoh }\end{array}$ \\
\hline
\end{tabular}

Adapunmetodepelatihan

yang

dilakukan akan bersifat:

- Teaching. Metode ini merupakan metode transfer knowledge dimana penyampaian materi akan dilakukan satu arah dari fasilitator kepada para peserta.

- Teach to Learn. Pada metode ini, peserta akan diberikan waktu untuk menerangkan apa yang telah diperoleh selama pelatihan kepada peserta lainnya. Hal ini dilakukan dengan keyakinan bahwa peserta telah mengerti apa yang disampaikan fasilitator ketika dapat menerangkannya kepada orang lain.

- Praktik (latihan). Para peserta akan berlatih melalui pengaplikasian teori yang diperoleh.

\section{HASIL DAN LUARAN 3.1 HASIL}

Kegiatan pelatihan berlangsung yang dimulai pada pukul 09.00-12.00 WIB bertempat di lingkungan sentra industri pengolahan batako di kota Cimahi. Kegiatan dilaksanakan dengan memulai pengenalan pada pemberi materi dan kemudian dilanjutkan dengan pengenalan situasi lingkungan dan kemudian di lanjut dengan pemberian materi mengenai persediaan atau inventory dimana memberikan pengertian pentingnya membuat perhitungan untuk persediaan agar pelaku usaha dapat memperkirakan pembelian persediaan agar tidak menumpuk dan menjadi rusak dalam artian kerusakan ketika penyimpanan, setelah itu peserta diajarkan untuk mengetahui pentingnya pembuatan layout atau tata letak agar para pelaku dapat mengerjakan usahanya secara efisien dari segi tempat, jarak dan gerakan. Setelah selesai peserta diberikan kesempatan untuk bertanya terhadap materi yang dilaksanakan pada saat pelatihan tersebut. Dengan sistem diskusi langsung pemberi materi dapat dengan mudah untuk menjelaskan manfaat-manfaat dari tema pelatihan tersebut dibandingkan hanya dengan peserta membaca modul saja. 
Melalui pelatihan langsung peserta menjadi tahu bagaimana cara membuat layout yang baik atau dengan memberikan bayangan (gambaran) secara langsung terhadap apa yang disebut dengan layout. Yang barikutnya yaitu pelatihan mengenai persediaan atau inventory dimana pemberi materi menanyakan dahulu kendalakendala yang dialami oleh para peserta terhadap persediaan untuk membuat batako disini agar kedua pihak juga lebih paham apa yang dibutuhkan dan apa yang akan menjadi solusinya. Dalam proses pembelajaran inventory di dalam modul juga tersedia bagaimana cara menghitung persediaan dengan mudah, serta diberikan contoh yang mudah untuk mengaplikasikannya dalam kondisi nyata. Cara tersebut setidaknya membantu peserta untuk memiliki gambaran agar tidak membeli bahan baku terlalu banyak dan menjadikan bahan baku tersebut menumpuk di lokasi produksi tersebut.

Faktor penghambat yang terjadi dalam pelatihan yang dilaksanakan adalah tidak tersedianya sarana dan prasarana fasilitas pendukung untuk menjalankan pelatihan di ruangan, akan tetapi hal tersebut tidak mengurangi semangat tim untuk memberikan materi, peserta pelatihan tidak dapat meninggalkan pekerjaannya dikarenakan pelatihan diadakan saat jam kerja dan peserta pelatihan sedang mengerjakan pesanan yang cukup banyak. Faktor pendukung yang terjadi dalam pelatihan yang dilaksanakan adalah dimana peserta antusias dan semangat dalam menjalankan pelatihan dan mereka lebih sering bertanya sehingga terjadi proses diskusi. Pelatihan dan diskusi dilakukan di lapangan secara langsung agar dapat memberikan contoh secara nyata kepada peserta pelatihan. Pelatihan ini mendapatkan dukungan dari masyarakat sekitar karena pelatihan ini diketahui oleh RW setempat.

\subsection{LUARAN}

Pelaksanaan pengabdian ini mempunyai target dan luaran:
1. Pelatihan dan Manual book atau modul untuk melakukan pelatihan manajemen persediaan dan tata letak yang mudah diaplikasikan para pelaku usaha sehingga usaha kedepannya lebih terorganisasi dengan baik.

2. Pelatihan juga langsung terjun ke lapangan dengan melihat kondisi sekitar dan memberikan contoh langsung kepada para pelaku usaha tersebut.

\section{Tabel 2.1 TabelLuaranCapaian}

\begin{tabular}{|c|c|c|}
\hline No & JenisLuaran & $\begin{array}{c}\text { IndikatorC } \\
\text { apaian }\end{array}$ \\
\hline 1. & $\begin{array}{l}\text { Publikasiilmiah di } \\
\text { jurnal/prosiding }\end{array}$ & Ada \\
\hline 2. & $\begin{array}{l}\text { Publikasipada media } \\
\text { massa (cetak/elektronik) }\end{array}$ & Tidak Ada \\
\hline 3. & $\begin{array}{l}\text { Peningkatanomzetpadamit } \\
\text { ra yang } \\
\text { bergerakdalambidangekon } \\
\text { omi }\end{array}$ & Tidak Ada \\
\hline 4. & $\begin{array}{l}\text { Peningkatankuantitasdank } \\
\text { ualitasproduk }\end{array}$ & Ada \\
\hline 5. & $\begin{array}{l}\text { Peningkatanpemahamand } \\
\text { anketerampilanmasyaraka } \\
\mathrm{t}\end{array}$ & Ada \\
\hline 6. & $\begin{array}{l}\text { Peningkatanketentraman/ } \\
\text { kesehatanmasyarakat } \\
\text { (mitramasyarakatumum) }\end{array}$ & Tidak Ada \\
\hline 7. & $\begin{array}{l}\text { Jasa, model, } \\
\text { rekayasasosial, sistem, } \\
\text { produk/barang }\end{array}$ & Tidak Ada \\
\hline 8. & $\begin{array}{l}\text { Hakkekayaanintelektual } \\
\text { (paten, paten sederhana, } \\
\text { hakcipta, merekdagang, } \\
\text { rahasiadagang, } \\
\text { desainprodukindustri, } \\
\text { perlindunganvarietastana }\end{array}$ & Tidak Ada \\
\hline
\end{tabular}




\begin{tabular}{|c|l|c|}
\hline & $\begin{array}{l}\text { man, } \\
\text { perlindungantopografi) }\end{array}$ & \\
\hline 9. & Buku ajar & Tidak Ada \\
\hline
\end{tabular}

\section{KESIMPULAN}

Kesimpulan dari pengabdian ini adalah bahwa masih sangat dibutuhkan pembelajaran bagi masyarakat sekitar dalam mengelola usahanya dari segi pengaturan tata letak dan pengaturan persediaan dimana tata letak dapat memaksimalkan tempat yang ada sedangkan untuk persediaan para pengusaha dapat memaksimalkan biaya.

\section{DAFTAR PUSTAKA}

Heizer, J. dan Render, B. (2009). Manajemen Operasi. Buku 1 edisi 9. Jakarta: Salemba Empat 